\title{
CXCR4 Antagonist BL-8040
}

National Cancer Institute

\section{Source}

National Cancer Institute. CXCR4 Antagonist BL-8040. NCI Thesaurus. Code C88309.

An orally bioavailable inhibitor of CXC Chemokine Receptor 4 (CXCR4) with potential antineoplastic activity. CXCR4 antagonist BL-8040 selectively binds to the chemokine receptor CXCR4, preventing the binding of stromal derived factor 1 (SDF-1 or CXCL12) to the CXCR4 receptor and subsequent receptor activation, which may result in decreased tumor cell proliferation and migration. In addition, inhibition of CXCR4 may induce mobilization of hematopoietic cells from the bone marrow into blood. The $\mathrm{G}$ proteincoupled receptor CXCR4 plays an important role in chemotaxis and ang iogenesis and is upregulated in several tumor cell types; SDF-1/CXCR4 interaction induces retention of hematopoietic cells in the bone marrow. 